Dhaka Univ. J. Biol. Sci. 26(1): 39-44, 2017 (January)

\title{
IN VITRO EFFECTS OF PLANT EXTRACTS AND FUNGICIDES TO CONTROL WILT OF BRINJAL (SOLANUM MELONGENA L.)
}

\author{
Md Ariful Islam, S Shamsi, S Hosen AND MA Bashar* \\ Department of Botany, University of Dhaka, Dhaka-1000, Bangladesh \\ Key words: In vitro, Plant extracts, Fungicides, Fusarium oxysporum, F. solani, Brinjal wilt
}

\begin{abstract}
Five fungicides viz., Bavistin DF, Capvit 50 WP, Dithane M-45, Greengel 72 WP and Tilt 250 EC were selected to evaluate in vitro efficacy against Fusarium oxysporum and F. solani at 100, 200, 300, 400 and 500 ppm following poisoned food technique. Bavistin, Capvit and Tilt were found to be most effective inhibitor against the test pathogens isolated from brinjal wilt. Bavistin and Tilt completely inhibited the growth of F. oxysporum and F. solani at all the tested concentrations. Out of five plant extracts, Allium sativum identified as the promising botanical fungicide for testing against wilted plants of brinjal. The result of present study will be helpful in suggesting some effective plant extracts and fungicides for controlling wilting of brinjal.
\end{abstract}

\section{Introduction}

Brinjal (Solanum melongena L.) is one of the most popular vegetables in Bangladesh belongs to Solanaceae ${ }^{(1)}$. It is popularly known as eggplant, aubergine, melongene, brinjal, or guinea squash. Eggplant is the second most important vegetable crop next to potato in Bangladesh in respect of its acreage and production ${ }^{(2)}$. In Bangladesh, brinjal is cultivated widely in the field for commercial purpose as well as in the homeyard and kitchen garden. The total area used for kharif and rabi brinjal cultivation in Bangladesh during 2013 - 2014 growing year was 42314 and 73409 acres with a total annual production of 133633 and 310510 metric tons, respectively(3). The yield potential of eggplant is low in Bangladesh compared to other countries. Among the various constraints for brinjal cultivation, diseases play an important role. The crop is known to suffer from more than 70 different diseases ${ }^{(4)}$. About 13 different diseases so far recorded in Bangladesh (5,6). Major fungal diseases of brinjal are leaf spot, fruit rot, black rot, leaf blight, foot rot, wilt, etc. Among those diseases Fusarium wilt of eggplant has been treated as one of the major constrains in eggplant cultivation in Bangladesh ${ }^{(7)}$.

Nowadays, many inorganic and organic fungicides are used frequently to control plant diseases ${ }^{(8)}$. Various workers in different countries evaluated the efficacy of various fungicides against Fusarium oxysporum and F. solani under laboratory and field conditions $^{(9-11)}$. All these fungicides are not available in Bangladesh. Therefore, it is necessary to test the efficacy of the fungicides against the pathogens.

"Author for correspondence: 〈botanybashar@yahoo.com>. 
In recent years, some workers on the fungi toxicity of extracts of various parts of higher plants have indicated the possibility of their exploitation as natural fungi toxicants for controlling plant diseases ${ }^{(12-15)}$. Plant metabolites and plant based pesticides appear to be one of the better alternatives as they are known to have minimal environmental impact and danger to consumers in contrast to the synthetic pesticides ${ }^{(16)}$. A few attempts have been made for the control of mycoflora associated with brinjal by fungicides and plant extracts. Therefore, the present investigation was ascertained to investigate the inhibitory effect of extracts of five plant species and fungi toxicity of five fungicides on isolated pathogen of wilted brinjal under in vitro conditions.

\section{Materials and Methods}

Wilted brinjal plants were collected from selected fields of Bangladesh Agriculture Development Corporation (BADC) in Gazipur and research field of the Botanical Garden at Curzon Hall, Dhaka University during October, 2015 to April, 2016. Samples were collected in separate sterile polyethylene bags, labeled properly and then brought to the laboratory for isolation of fungi following "Tissue planting method" on PDA medium. Fifty inocula, each measuring $2 \mathrm{~mm}^{2}$ sized were cut separately with a pair of sterilize scissors and kept in a separate sterilized Petri plate. The inocula were washed with sterile water and then surface sterilized by dipping in 10\% Chlorox solution for three minutes. The inocula were again washed with sterile water. A total of 30 inocula were placed separately on 10 sterilized Petri plates containing $15 \mathrm{ml}$ of PDA medium with an addition of 1 drop (ca. $0.03 \mathrm{ml}$ ) of lactic acid and incubated in an incubator $\left(25 \pm 2^{\circ} \mathrm{C}\right)$ for 7 days. Identification of the isolates was made following the standard reference books ${ }^{(17,18)}$.

Five fungicides viz., Bavistin DF, Capvit 50 WP, Dithane M-45, Greengel 72 WP and Tilt 250 EC were collected from the Krishi Upokoron Biponi Kendro, Khamarbari, Farmgate, Dhaka. For each fungicide, a stock solution of 10000 ppm was prepared. The calculated amount of stock solution of fungicide as supplemented with sterilized PDA medium to get the concentration of 100, 200, 300, 400 and 500 ppm, respectively. In control set, required amount of water was used instead of a fungicide. Then $15 \mathrm{ml}$ of medium was poured in each Petri plate and allowed them to solidify.

For in vitro effect of five plant extracts, viz., Allium sativum (bulb), Azadirachta indica (leaf), Cassia alatam (leaf), Citrus limon (leaf) and Datura metel (leaf) were selected on the radial growth of test pathogens. The desired parts of each plant were thoroughly washed in tap water, air dried and were prepared by crushing to known weight of fresh materials with distilled water in ratio of $1: 1(\mathrm{w} / \mathrm{N})$. The pulverized mass of a plant part was squeezed through four-folds of fine cloth and the extracts were centrifuged at $3000 \mathrm{rpm}$ for 20 minutes to remove particles. The supernatants were filtered through Whatman filter paper No. 1 and the filtrate was collected in $250 \mathrm{ml}$ Erlenmeyer flask. The requisite amount of the filtrate of each plant extract was mixed with PDA medium to get 5, 10, 15 
and $20 \%$ concentration. In control set, required amount of water was used instead of plant extract. Five $\mathrm{mm}$ mycelial agar disc cut from the margin of actively growing culture of test pathogens and then it was inoculated at the centre of the plate. All the Petri plates were incubated at $25 \pm 2^{\circ} \mathrm{C}$. The radial growth of the test pathogen colonies were measured after 7 days. The per cent growth inhibition of each test pathogen was calculated using the following formula:

$$
\mathrm{I}=\frac{\mathrm{C}-\mathrm{T}}{\mathrm{C}} \times 100
$$

where, $\mathrm{I}=$ Per cent growth inhibition, $\mathrm{C}=$ Growth in control, $\mathrm{T}=$ Growth in treatment. The results were statistically analyzed by $\mathrm{t}$ test following Steel and Torrie ${ }^{(19)}$.

\section{Results and Discussion}

Five fungi viz., Aspergillus flavus, A. fumigatus, A. niger, Fusarium oxysporium and F. solani were isolated from the wilted brinjal. Identification of these fungi was determined following the standard reference books ${ }^{(17,18)}$. Among the isolated fungi Fusarium oxysporium and F. solani were selected as test pathogens owing to their higher percentage of occurrence and previous reports as pathogenic organisms ${ }^{(20)}$.

The results of fungicides on the radial growth of Fusarium oxysporum and F. solani at 100, 200, 300, 400 and 500 ppm are presented in Tables 1 and 2. Out of five fungicides, complete inhibition of the radial growth of Fusarium oxysporum was observed with Bavistin and Tilt at all the tested concentrations (Table 1). Greengel, Dithane and Capvit showed 73.80, 58.33 and 30\% growth inhibition of Fusarium oxysporum, respectively at 500 ppm (Table 1). The complete inhibition of growth of Fusarium solani was also observed with Bavistin and Tilt at all the concentrations (Table 2). Greengel and Dithane showed 68.28 and $48.57 \%$ growth inhibition of Fusarium solani, respectively at 500 ppm (Table 2).

Bashar et al.(14) reported the effects of Bavistin, Dithane and Tall on the radial growth of Fusarium oxysporum and F. solani at 400 ppm only. Chakraborty et al.(11) reported that, at $0.5 \%$ dose, bavistin happened to be the most efficient one contributing the highest inhibition $(83.7 \%)$ of growth of the $F$. solani causing wilt of brinjal under in vitro condition. Bashar(21) reported that bavistin checked the complete growth of $F$. oxysporum f. sp. ciceri, causal agent of chickpea wilt at $100 \mathrm{ppm}$ concentration. He also noted that dithane failed to check the growth of the pathogen completely even at 3,000 ppm.

Laboratory evaluation of fungicides revealed that all the fungicides cause partial or complete inhibition of F. oxysporum and F. solani at $500 \mathrm{ppm}$ (Tables 1 and 2). The same fungicides also showed different effects on different pathogens in the present investigation due to the selection of different strains of test pathogens. 
Results of plant extracts on the radial growth of F. oxysporum and F. solani at 5, 10, 15 and $20 \%$ concentration are shown in Tables 3 and 4 . All the plant extracts showed varied degree of growth inhibition of the pathogens at different concentrations. Out of the five plant extracts, Allium sativum and Cassia alata showed 100\% radial growth inhibition of $F$. oxysporum at $20 \%$ concentration followed by Azadirachta indica (55.55\%), Datura metel

Table 1. Per cent inhibition of radial growth of Fusarium oxysporum at different concentrations of fungicides.

\begin{tabular}{llllll}
\hline \multirow{2}{*}{$\begin{array}{l}\text { Name of } \\
\text { fungicides }\end{array}$} & \multicolumn{4}{c}{$\%$ inhibition of radial growth at different concentrations $(\mathrm{ppm})$} \\
\cline { 2 - 6 } & 100 & 200 & 300 & 400 & 500 \\
\hline Bavistin DF & $100^{\mathrm{a}}$ & $100^{\mathrm{a}}$ & $100^{\mathrm{a}}$ & $100^{\mathrm{a}}$ & $100^{\mathrm{a}}$ \\
Capvit 50 WP & 10.00 & 15.00 & $20.00^{\mathrm{c}}$ & $25.00^{\mathrm{c}}$ & $30.00^{\mathrm{c}}$ \\
Dithane M-45 & $22.22^{\mathrm{b}}$ & $30.55^{\mathrm{b}}$ & $52.77^{\mathrm{b}}$ & $55.55^{\mathrm{b}}$ & $58.33^{\mathrm{b}}$ \\
Greengel 72 WP & $38.09^{\mathrm{b}}$ & $47.61^{\mathrm{b}}$ & $59.52^{\mathrm{b}}$ & $64.28^{\mathrm{a}}$ & $73.80^{\mathrm{a}}$ \\
Tilt 250 EC & $100^{\mathrm{a}}$ & $100^{\mathrm{a}}$ & $100^{\mathrm{a}}$ & $100^{\mathrm{a}}$ & $100^{\mathrm{a}}$ \\
\hline
\end{tabular}

$\mathrm{a}, \mathrm{b}$ and $\mathrm{c}$ indicate significance of $\mathrm{t}$ value at $\mathrm{p}=0.001,0.01$ and 0.05 , respectively. In a row, figures with same letter do not differ significantly, whereas figures with dissimilar letter differ significantly (as per DMRT).

Table 2. Per cent inhibition of radial growth of Fusarium solani at different concentrations of fungicides.

\begin{tabular}{llllll}
\hline \multirow{2}{*}{$\begin{array}{l}\text { Name of } \\
\text { fungicides }\end{array}$} & \multicolumn{4}{c}{ \% inhibition of radial growth at different concentrations (ppm) } \\
\cline { 2 - 6 } & 100 & 200 & 300 & 400 & 500 \\
\hline Bavistin DF & $100^{\mathrm{a}}$ & $100^{\mathrm{a}}$ & $100^{\mathrm{a}}$ & $100^{\mathrm{a}}$ & $100^{\mathrm{a}}$ \\
Capvit 50 WP & $17.14^{\mathrm{c}}$ & $28.57^{\mathrm{b}}$ & $35.71^{\mathrm{b}}$ & $100^{\mathrm{a}}$ & $100^{\mathrm{a}}$ \\
Dithane M-45 & $28.57^{\mathrm{b}}$ & $35.71^{\mathrm{b}}$ & $44.28^{\mathrm{a}}$ & $45.71^{\mathrm{a}}$ & $54.47^{\mathrm{a}}$ \\
Greengel 72 WP & $14.63^{\mathrm{c}}$ & $24.39^{\mathrm{b}}$ & $48.78^{\mathrm{b}}$ & $56.09^{\mathrm{b}}$ & $68.29^{\mathrm{a}}$ \\
Tilt 250 EC & $100^{\mathrm{a}}$ & $100^{\mathrm{a}}$ & $100^{\mathrm{a}}$ & $100^{\mathrm{a}}$ & $100^{\mathrm{a}}$ \\
\hline
\end{tabular}

(33.33) and Citrus limon (25\%). The inhibition of the test pathogens increases with the increase of the concentration of the plant extracts in culture medium (Table 3). The order of effectiveness against F. oxysporumat $20 \%$ was $A$. sativum $=C$. alata $(100 \%)>A$. indica $(55.55 \%)>$ D. metel $(33.33 \%)>$ C. limon $(25 \%)$ (Table 3). The highest inhibition of radial growth of $F$. solani was observed with $A$. sativum and $C$. alata at $20 \%$ which was followed by $A$. indica $(80.48 \%)$, C. limon $(60.97 \%)$ and D. metel $(28.12 \%)$ (Table 4$)$. The order of effectiveness against $F$. solaniat $20 \%$ was $A$. sativum $=C$. alata $(100 \%)>A$. indica $(80.48 \%)>$ C. limon $(60.97 \%)>$ D. metel $(28.12 \%)$ (Table 4$)$.

Bashar and Chakma ${ }^{(13)}$ reported that the plant extracts of $C$. alata, A. indica, A. sativum and D. metel showed $74.78,62.03,34.21$ and $34.18 \%$ growth inhibition of $F$. oxysporum at 
$20 \%$ concentration, respectively. Again, D. metel, A. indica, A. sativum and C. alata showed $66.67,57.14,53.85$ and $50 \%$ growth inhibition of $F$. solani at $20 \%$ concentration, respectively. The same plant extracts also showed different effects on same pathogens in the present investigation. This variation might be due to selection of different strains of test pathogens.

Table 3. Effect of plant extracts on the radial growth of Fusarium oxysporum at different concentrations.

\begin{tabular}{|c|c|c|c|c|}
\hline \multirow[t]{2}{*}{$\begin{array}{l}\text { Name of } \\
\text { plants }\end{array}$} & \multicolumn{4}{|c|}{$\begin{array}{l}\% \text { inhibition of radial growth of the pathogen at different } \\
\text { concentrations (\%) }\end{array}$} \\
\hline & 5 & 10 & 15 & 20 \\
\hline Allium sativum & $100^{\mathrm{a}}$ & $100^{\mathrm{a}}$ & $100^{\mathrm{a}}$ & $100^{a}$ \\
\hline Azadirachta indica & $38.88^{\mathrm{b}}$ & $44.44^{\mathrm{a}}$ & $48.88^{a}$ & $55.55^{\mathrm{b}}$ \\
\hline Cassia alata & $49.14^{\mathrm{b}}$ & $58.25^{\mathrm{b}}$ & $76.07^{b}$ & $100^{\mathrm{a}}$ \\
\hline Citrus limon & $10.00^{c}$ & $15.00^{c}$ & $20.00^{c}$ & $25.00^{c}$ \\
\hline Datura metel & $15.15^{c}$ & $24.24^{\mathrm{b}}$ & $30.30^{\mathrm{b}}$ & $33.33^{b}$ \\
\hline
\end{tabular}

Table 4. Effects of plant extracts on the radial growth of Fusarium solani at different concentrations.

\begin{tabular}{|c|c|c|c|c|}
\hline \multirow[t]{2}{*}{$\begin{array}{l}\text { Name of } \\
\text { plants }\end{array}$} & \multicolumn{4}{|c|}{$\begin{array}{l}\% \text { inhibition of radial growth of the pathogen at different } \\
\text { concentrations }(\%)\end{array}$} \\
\hline & 5 & 10 & 15 & 20 \\
\hline Allium satioum & $55.55^{\mathrm{b}}$ & $66.66^{b}$ & $100^{\mathrm{a}}$ & $100^{a}$ \\
\hline Azadirachta indica & $58.53^{a}$ & $65.85^{\mathrm{a}}$ & $75.60^{\mathrm{a}}$ & $80.48^{\mathrm{a}}$ \\
\hline Cassia alata & $53.33^{b}$ & $64.44^{\mathrm{a}}$ & $86.66^{a}$ & $100^{a}$ \\
\hline Citrus limon & $36.58^{\mathrm{b}}$ & $43.90^{\mathrm{b}}$ & $51.21^{b}$ & $60.97^{a}$ \\
\hline Datura metel & $12.50^{c}$ & $18.75^{\mathrm{c}}$ & $21.87^{c}$ & $28.12^{\mathrm{b}}$ \\
\hline
\end{tabular}

The results of this study identified Bavistin, Capvit and Tilt for wilted plants of brinjal as best inhibiting chemical fungicides. Out of five plant extracts, A. sativum identified as promising botanical fungicide for further investigation against wilted plants of brinjal.

\section{References}

1. Ahmed ZU, MA Hassan, ZNT Begum, M Khondker, SMH Kabir, M Ahmed and ATA Ahmed (eds.) 2008. Encyclopedia of Flora and Fauna of Bangladesh, Vol. 10. Angiosperms: Dicotyledons (Ranunculaceae - Zygophyllaceae). Bangladesh Asiat. Soc., Dhaka. pp. 580.

2. BBS 2005. Year Book of Agricultural Statistics of Bangladesh. Statistics Division, Bangladesh Bureau of Statistics (Monthly Statistical Bulletin, Bangladesh, December 2003). Ministry of Planning, Government of the People's Republic of Bangladesh. p. 55. 
3. BBS 2014. Statistical Year book of Bangladesh. 26th series, Statistics Division, Ministry of Planning, Govt. of the People's Republic of Bangladesh, Dhaka. pp. 405.

4. Rangaswami G and CN Sambandam 1960. Alternaria melongena causing leaf spot and fruit scab of eggplant and fruit rot of brinjal. Mycologia 52: 517-520.

5. Das GP, S Ramaswamy and MA Bari 2000. Integrated crop management practices for the control of the brinjal shoot and fruit borer in Bangladesh. DAE-DANIDA Strengthening Plant Protection Services (SPPS) Project. Dept. of Agril. Extension. Khamarbari, Dhaka. pp. 12.

6. Rashid MM 2000. A Guidebook of Plant Pathology. Dept. of Plant Pathology. HSTU. Dinajpur. pp. 58.

7. Ali M 1993. Workshop on Research and Development of vegetable crops. 9-10 March. Institute of Post Graduate Studies in Agriculture (IPSA), Gazipur-1703. pp. 68-75.

8. Mehrotra RS 2000. Plant Pathology. Tata McGraw Hill Publishing Co., New Delhi. pp. 771.

9. Andrabi M, A Vaid and VK Razdan 2011. Evaluation of different measures to control wilt causing pathogens in chickpea. J. Plant Prot. Res. 51(1).

10. Chandel S and R Deepika 2011. Recent advances in management and control of Fusarium yellows in Gladiolus species. J. Fruit and Ornamental Plant Res. 18(2): 361-380.

11. Chakraborty MR, NC Chatterjee and TH Quimio 2009. Integrated management of Fusarial wilt of eggplant (Solanum melongena) with soil solarization. Mycologia Aplicada International 21 (1): 25-36.

12. Sharmin S and S Shamsi 2013. In vitro control of five pathogenic fungi isolated from groundnut (Arachis hypogaea L.). J. Asiat. Soc. Bangladesh, Sci. 39(1): 27-33.

13. Bashar MA and M Chakma 2014. In vitro control of Fusarium solani and F. oxysporum the causative agent of brinjal wilt. Dhaka Univ. J. Biol. Sci. 23(1): 53-60.

14. Bashar MA, R Akter and KS Hossain 2015. Potential fungicides and plant extracts against fusarial wilt of brinjal. Dhaka Univ. J. Biol. Sci. 24(2): 209-213.

15. Chowdhury P, MA Bashar and S Shamsi 2015. In vitro evaluation of fungicides and plant extracts against pathogenic fungi of two rice varieties. Bangladesh J. Bot. 44(2): 251-259.

16. Verma J and NK Dubey 1999. Prospectives of botanical and microbial products as pesticides of tomorrow. Current Science 76: 172-179.

17. Booth C 1971. The genus Fusarium. Commonwealth Mycological Institute, Kew, Surrey, England. pp. 237.

18. Thom C and KB Raper 1945. A Manual of the Aspergilli. The Williams \& Wilkins Company. Baltimore, USA, pp. 373.

19. Steel RGD and JH Torrie 1960. Principles and Procedures of Statistics. Mac Graw Hill Book Co., New York. pp. $14+481$.

20. Aktar MT, KS Hossain and MA Bashar 2014. Antagonistic potential of rhizosphere fungi against leaf spot and fruit rot pathogens of brinjal. Bangladesh J. Bot. 43(2): 213-217.

21. Bashar MA 1992. Laboratory evaluation of some pesticides on Fusarium oxysporum f. sp. ciceri causing wilt of chickpea. Bangladesh J. Bot. 21(1): 157-159. 